\title{
The provenance of deep groundwater and its relation to arsenic distribution in the northwestern Hetao Basin, Inner Mongolia
}

\author{
Shuai Liu ${ }^{1,2}$, Huaming Guo ${ }^{1,2, *}$, Hai $\mathrm{Lu}^{3}$, Zhuo Zhang ${ }^{2}$, and Weiguang Zhao ${ }^{2}$ \\ ${ }^{1}$ State Key Laboratory of Biogeology and Environmental Geology, China University of Geosciences, \\ Beijing 100083, P.R. China \\ ${ }^{2}$ School of Water Resources and Environment, China University of Geosciences (Beijing), Beijing \\ 100083, P.R. China \\ ${ }^{3}$ The National Institute of Metrology, Beijing 100013, PR China
}

\begin{abstract}
High arsenic (As) groundwater has been found in deep aquifer of the northwestern Hetao Basin. Little is known about the source of high As deep groundwater and its role in As distribution. Based on strontium ( $\mathrm{Sr}$ ) isotopes, this study aims to investigate the provenance of high arsenic deep groundwater (DGW). ${ }^{87} \mathrm{Sr} /{ }^{86} \mathrm{Sr}$ in DGW gradually decreased from the alluvial fans to the flat plain. Results show that fissure water, plagioclase dissolution, and shallow groundwater (SGW) controlled the ${ }^{87} \mathrm{Sr} /{ }^{86} \mathrm{Sr}$ variation. Although the reductive dissolution of As-containing iron oxide controlled the As mobilization, the leaching of phyllite and meta-basalt, incongruent dissolution of plagioclase, and vertical mixing with SGW also played an important role in increasing As concentrations in DGW approximately along the flow paths.
\end{abstract}

\section{Introduction}

In China, high arsenic (As) groundwater has mainly been found in inland basins like the Yinchuan basin, the Hetao basin and Songnen basin [1]. Especially in the Hetao basin, high As groundwater has been observed in both shallow and deep aquifers [1,2]. Since deep groundwater is mainly used as water source for irrigation, groundwater As would enter the food chain, and thus threaten the health of local residents [3]. However, most studies are concentrated on aqueous geochemistry and its roles in As mobilization. With regard to source of high arsenic groundwater, it remains an open question. Strontium isotopes have been widely used to trace the source of contaminants in groundwater due to its isotopic stability $[4,5]$. Based on evaluating strontium isotope characteristics, this study aims at: (1) characterizing the spatial distribution of ${ }^{87} \mathrm{Sr} /{ }^{86} \mathrm{Sr}$ and the sources of high arsenic in DGW, and (2) revealing the relationship between sources of high arsenic DGW and arsenic mobilization.

\footnotetext{
*Corresponding author: hmguo@ cugb.edu.cn.
} 


\section{Material and methods}

\subsection{Study area}

The Hetao basin is located in the northwest of Inner Mongolia, to the south of Langshan mountains and to the north of Yellow River. It is a typical semiarid to arid inland basin. There are clay layers with several meters in thickness at depths around $40 \mathrm{~m}$ below land surface. Shallow groundwater (SGW) is hosted overlying clay layers, while deep groundwater (DGW) occurs underlying the clay layers [2].

\subsection{Sampling and analysis}

Sixty-two water samples were collected in the study area with an area of around $90 \mathrm{~km}^{2}$ during July to August of 2016, including 57 DGW samples and 5 SGW samples (Fig.1). Groundwater was sampled after parameters like temperature, $\mathrm{pH}$, Eh, and EC became stable. Laboratory analyses were carried out for determination of major ions, trace elements and DOC. ${ }^{87} \mathrm{Sr} /{ }^{86} \mathrm{Sr}$ analyses were conducted on Isoprobe T TIMS after sample purification through $\mathrm{Sr}$-spec resin. In addition, selected six sediment samples were dried and milled for $\mathrm{XRD}$ analysis.

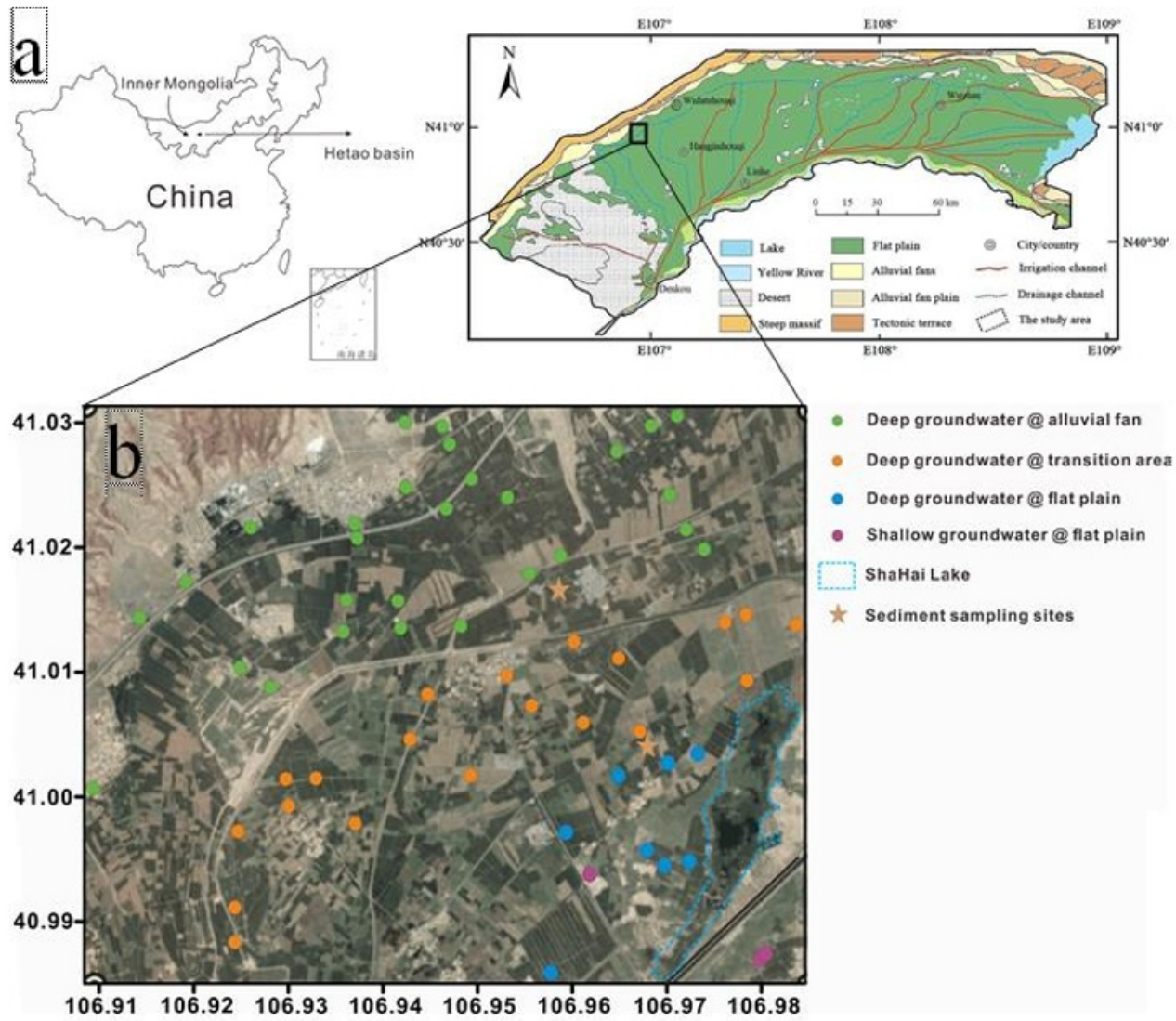

Fig. 1. Locations of the study area (a) and water samples sites (b) 


\section{Results and Discussion}

\subsection{Distribution of ${ }^{87} \mathrm{Sr} /{ }^{86} \mathrm{Sr}$ and As}

The ${ }^{87} \mathrm{Sr} /{ }^{86} \mathrm{Sr}$ in DGW decreased from the alluvial fan to the flat plain with the range from 0.7152 to 0.7117 (Fig. 1b). However, arsenic concentration showed an increasing trend with the range from 0.53 to $447 \mu \mathrm{g} / \mathrm{L}$, which is in line with previous studies [6]. There was a negative correlation between As concentrations and ${ }^{87} \mathrm{Sr} /{ }^{86} \mathrm{Sr}$. Around $77.6 \%$ of samples exceeded the $10 \mu \mathrm{g} / \mathrm{L}$ (the maximum concentration level recommended by the WHO). Arsenic concentrations below $10 \mu \mathrm{g} / \mathrm{L}$ mainly occurred in alluvial fans, especially near the front of mountain area.

\subsection{Source of high arsenic groundwater and its relation to arsenic distribution}

Since $\mathrm{Ca}^{2+}$ and $\mathrm{Sr}^{2+}$ have equal charge and similar size, they have similar geochemical behavior. We identified three sources (S1, S2 and S3) of high arsenic groundwater based on ${ }^{87} \mathrm{Sr} /{ }^{86} \mathrm{Sr}$ and $\mathrm{Sr} / \mathrm{Ca}$.

$\mathrm{S} 1$ is the fissure water recharging, mainly located near the front of mountain area in alluvial fan. Groundwater exhibited higher ${ }^{87} \mathrm{Sr} /{ }^{86} \mathrm{Sr}$ than that in rainfall $\left({ }^{87} \mathrm{Sr} /{ }^{86} \mathrm{Sr}=0.7134\right)$, and had the narrow range of $\mathrm{Sr} / \mathrm{Ca}$ from 0.005 to 0.01 . The fissure water was considered to be under-saturated or just over-saturated with respect to calcite. Therefore, these indices indicated that the bedrock fissure water derived from rainfall recharged the deep groundwater. However, As in DGW was less than $50 \mu \mathrm{g} / \mathrm{L}$, and more than $61 \%$ of samples had As content less than $10 \mu \mathrm{g} / \mathrm{L}$. DGW with ${ }^{87} \mathrm{Sr} /{ }^{86} \mathrm{Sr}>0.7134$ largely originated from fissure water, usually had low As concentration due to the direct recharge from bedrock fissure groundwater under oxic conditions.

$\mathrm{S} 2$ is related to incongruent dissolution of plagioclase. It is located in the transition zone between the alluvial fans and the flat plain. Groundwater ${ }^{87} \mathrm{Sr} /{ }^{86} \mathrm{Sr}$ in this zone decreased further from 0.7134 to 0.7117 , but $\mathrm{Sr} / \mathrm{Ca}$ increased from 0.008 to 0.027 . Plagioclase commonly exits in sediments of the study area based on XRD analyses, not just in the transition zone [6]. Around 69\% DGW samples had arsenic concentrations greater than 50 $\mu \mathrm{g} / \mathrm{L}$, and more than $55 \%$ had arsenic concentrations greater than $150 \mu \mathrm{g} / \mathrm{L}$. On the one hand, the incongruent dissolution of plagioclase can generate $\mathrm{OH}^{-}$and make $\mathrm{pH}$ maintain weakly alkaline (average 7.7, compared with 7.59 in S1). On the other hand, this kind of incongruent dissolution can decrease $\mathrm{Ca} / \mathrm{Na}$ in groundwater since calcite was over-saturated but Na-smectite was under-saturated. The appropriate $\mathrm{pH}$ and the decreasing $\mathrm{Ca} / \mathrm{Na}$ all favored desorption of As from Fe/Mn oxide/oxyhydroxide [7-9]. Both of these processes may be the reason that arsenic increased further in this area.

$\mathrm{S} 3$ is associated with the vertical mixing from SGW. It is located in the flat plain. Groundwater ${ }^{87} \mathrm{Sr} /{ }^{86} \mathrm{Sr}$ were approximately 0.7117 and $\mathrm{Sr} / \mathrm{Ca}$ continually increased from 0.017 to 0.037 . The ${ }^{87} \mathrm{Sr} /{ }^{86} \mathrm{Sr}$ of SGW was 0.7117 , and $\mathrm{Sr} / \mathrm{Ca}$ ranged from 0.025 to 0.032 . During the irrigation season (April - July), the decrease in DGW level could result in the recharge of SGW into DGW, especially in the flat plain [2]. SGW usually had the evapotranspiration signal due to the recharge from southern groundwater and/or surface water influenced by the diverted Yellow River with constant ${ }^{87} \mathrm{Sr} /{ }^{86} \mathrm{Sr}(0.7115)$ [10]. Arsenic concentration reached the highest level. Nine water samples had As concentrations exceeding $150 \mu \mathrm{g} / \mathrm{L}$, and five were above $300 \mu \mathrm{g} / \mathrm{L}$. The vertical mixing brought abundant fresh organics from near - surface to support bacteria utilization. Therefore, degradation of the fresh organics was coupled with the reductive dissolution of $\mathrm{Fe}$ (III) 
oxyhydroxides/oxides and the release of As [1].

\section{Conclusion}

Based on the variation of ${ }^{87} \mathrm{Sr} /{ }^{86} \mathrm{Sr}$ and $\mathrm{Sr} / \mathrm{Ca}$ in groundwater from the alluvial fan to the flat plain, the possible sources of high As DGW in the Hetao basin of Inner Mongolia were obtained, including fissure water recharging, incongruent dissolution of plagioclase and vertical mixing from SGW. In the alluvial where DGW comes from fissure water, As mobilization is limited with concentrations generally less than $50 \mu \mathrm{g} / \mathrm{L}$. In the transition area where DGW is related to incongruent dissolution of plagioclase, the appropriate $\mathrm{pH}$ and the decreasing $\mathrm{Ca} / \mathrm{Na}$ favored elevating groundwater As to more than $150 \mu \mathrm{g} / \mathrm{L}$. In the flat plain where DGW is associated with the vertical mixing with SGW, the fresh organics carried by SGW could be used by As/Fe reducing bacteria, and thus promote As release via As/Fe oxides reduction, leading to high As DGW with As $>300 \mu \mathrm{g} / \mathrm{L}$.

The study was financially supported by National Natural Science Foundation of China (Nos. 41672225 and 41825017), the Fundamental Research Funds for the Central Universities (No. 2652017193), and the Fok Ying Tung Education Foundation, China (Grant No. 131017).

\section{References}

1. H.M. Guo, D. Zhang, P. Ni, Y.S. Cao, F.L. Li, Y.F. Jia, H.L. Li, L. Wan, G.C. Wang, Appl. Geochem. 77, 15-23 (2017)

2. Y.F. Jia, H.M. Guo, Y.X. Jiang, Y. Wu, Y.Z. Zhou, J. Hydrol. 518, 410-420 (2014)

3. J.T. Tong, H.M. Guo, C. Wei, Sci. Total. Environ. 496, 479-487 (2014)

4. J.S. Harkness, T.H. Darrah, M.T. Moore, C.J. Whyte, P.D. Mathewson, T. Cook, A. Vengosh, Environ. Sci. Technol. 51, 12190-12199 (2017)

5. A. Vengosh, R. Coyte, J. Karr, J.S. Harkness, A.J. Kondash, L.S. Ruhl, R.B. Merola, G.S. Dywer, Environ. Sci. Technol. Lett. 3, 409-414 (2016)

6. H.M. Guo, Y.F. Jia, R.B. Wanty, Y.X. Jiang, W.G. Zhao, W. X, J.X. Shen, Y. Li, Y.S. Cao, Y. Wu, D. Zhang, C. Wei, Y.L. Zhang, W.G. Cao, A. Foster, Sci. Total. Environ. 541, 1172-1190 (2016)

7. Y.X. Wang, S.L. Shvartsev, C.L. Su, Appl. Geochem. 24, 641-649 (2009)

8. S.H. Do, Y.H. Jo, J.Y. Park, S.H. Hong, J. Hazard. Mater. 280, 322-30 (2014)

9. X. Guan, J. Ma, H. Dong, L. Jiang, Water. Res. 43, 5119-28 (2009)

10. Y.M. Deng, Y.X. Wang, T. Ma, Appl. Geochem. 24, 587-599 (2009) 